\title{
The Redemption of Things
}




\section{signale modern german letters, cultures, and thought}

Series editor: Peter Uwe Hohendahl, Cornell University

Signale: Modern German Letters, Cultures, and Thought publishes new English language books in literary studies, criticism, cultural studies, and intellectual history pertaining to the German-speaking world, as well as translations of important German-language works. Signale construes "modern" in the broadest terms: the series covers topics ranging from the early modern period to the present. Signale books are published under a joint imprint of Cornell University Press and Cornell University Library in electronic and print formats. Please see http://signale.cornell.edu/. 


\section{The Redemption of THINGS}

\section{Collecting and Dispersal in German Realism and Modernism}

\section{Samuel Frederick}

A Signale Book

Cornell University Press and Cornell University Library ITHACA AND LONDON 
Cornell University Press and Cornell University Library gratefully acknowledge the College of Arts \& Sciences, Cornell University, for support of the Signale series.

\section{Copyright @ 2021 by Cornell University}

All rights reserved. Except for brief quotations in a review, this book, or parts thereof, must not be reproduced in any form without permission in writing from the publisher. For information, address Cornell University Press, Sage House, 512 East State Street, Ithaca, New York 14850.

First published 2021 by Cornell University Press and Cornell University Library

\section{Library of Congress Cataloging-in-Publication Data}

Names: Frederick, Samuel, author.

Title: The redemption of things: collecting and dispersal in German realism and modernism / Samuel Frederick.

Description: Ithaca [New York]: Cornell University Press and Cornell University Library, 2021. I Series: Signale: modern German letters, cultures, and thought I Includes bibliographical references and index.

Identifiers: LCCN 2021011477 (print) I LCCN 2021011478 (ebook) I ISBN 9781501761553 (hardback) I ISBN 9781501761560 (paperback) I ISBN 9781501761584 (pdf) I ISBN 9781501761577 (epub)

Subjects: LCSH: Object (Aesthetics) I Collectors and collecting. I German literature-19th century-History and criticism. I

German literature-20th century-History and criticism.

Classification: LCC BH301.O24 F74 2022 (print) I LCC BH301.O24

(ebook) I DDC 830.9/353-dc23

LC record available at https://lccn.loc.gov/2021011477

LC ebook record available at https://lccn.loc.gov/2021011478 
For Henry,

collector extraordinaire 
